\title{
Trzy razy res publica: Thomas Smith, Gasparo Contarini i Wawrzyniec Goślicki
}

Will Kymlicka, analizując tendencje rozwojowe współczesnej filozofii politycznej, przywołuje opinię, która zdaje się wyrażać przekonanie zdecydowanej większości badaczy opisujących rzeczywistość społeczeństw demokratycznych. Jak pisze:

„Prężność i stabilność dzisiejszych demokracji zależy nie tylko od sprawiedliwości głównych instytucji, ale także od cech i nastawienia obywateli, np. od ich poczucia tożsamości i od tego, jak postrzegają jej potencjalnie konkurencyjne formy: tożsamość narodową, lokalną, etniczną, czy religijną; od ich zdolności do tolerancji oraz do współpracy z tymi, którzy się od nich różnią; od ich woli uczestnictwa w życiu politycznym, aby służyć dobru wspólnemu i rozliczać z takiej służby władze; od ich powściągliwości i osobistej odpowiedzialności w kwestii oczekiwań ekonomicznych, a także od ich indywidualnych decyzji, które mogą wpłynąc na ich stan zdrowia i środowiska. Bez obywateli posiadających takie cechy demokracją trudno rządzić, a nawet staje się ona niestabilna"”.

Związek demokracji, a szerzej - wszelkich rozwiązań ustrojowych - z, ,jakością" obywateli nie jest zagadnieniem nowym. Wręcz przeciwnie, należy do najstarszych problemów filozofii politycznej, rozważanych gruntownie już w starożytnej Grecji przez autorów takich jak Platon i Arystoteles. Może nawet nigdy potem zależności tego rodzaju nie były tak widoczne, jak właśnie w niewielkiej greckiej polis, gdzie stosunkowo mała liczba obywateli nadawała polityczne znaczenie działaniom i cechom każdego z nich. W dzisiejszych warunkach takie upolitycznienie ,indywidualności” (za jaką chcemy uważać każdego z nas) jest nie tylko niemożliwe, ale zdaniem wielu wręcz szkodliwe. A jednak fakt, że zagadnienie „cech i nastawienia obywateli” powraca właśnie teraz, ma swoją wagę. Poza wszystkim innym, zakrawa na pewien znaczący paradoks, kwestionujący postrzeganie europejskiej tradycji

\footnotetext{
${ }^{1}$ W. Kymlicka, Wspótczesna filozofia polityczna, Warszawa 2009, s. 348.
} 
politycznej jako procesu o - przynajmniej en bloc - postępowym charakterze. Nie tylko sugeruje on powtarzalność, a tym samym uniwersalność problemów politycznych, przed którymi staje każda próba stworzenia trwałego porządku społeczno-politycznego, ale ukazuje swoiste intelektualne pokrewieństwo między pokoleniami odległymi od siebie o setki, a dziś już nawet tysiące lat. Pokrewieństwo, do którego raczej nie lubimy się przyznawać, traktując przeszłość jako zastygłą i przebrzmiałą „,historię”, przygotowującą wprawdzie naszą teraźniejszość, lecz dla dalszego jej rozwoju bezwartościową. Jest w tym stwierdzeniu nieco przesady, ale przeszłość kojarzy się coraz częściej z czymś definitywnie minionym i nie tak łatwo przekonać nas do uwzględnienia jej roszczeń przy projektowaniu przyszłości. W świecie, z którym trudno nawet być „na bieżąco”, bo coraz szybciej wymienia on stare rzeczy na nowe, to co było przestaje się liczyć i traktowane jest raczej jako przeszkoda w pielęgnowaniu kreatywnego, dynamicznego i „na czasie” podejścia do rzeczywistości. $\mathrm{Z}$ drugiej strony - może z przekory, może dla odrobiny wytchnienia, a może z uwagi na dialektyczny charakter naszego myślenia i działania - w tym samym świecie odradza się zainteresowanie kwestiami na tyle ogólnymi, że wyłączonymi spod presji dziejowego przyspieszenia: wartościami, sensem życia, rozumieniem dobra. Jednym słowem, zainteresowanie Filozofią przez duże „F”, która w odniesieniu do relacji przebiegających w sferze publicznej staje się filozofią polityczną. Jest z tym związany pewien trend, który może cieszyć historyka myśli politycznej. Otóż właśnie „historia myśli”, która z natury nie jest ani czystą historią (bo myślenia nie da się tak po prostu umieścić na linii czasu), ani czystym myśleniem (bo musi to być myślenie, którego historię da się odtworzyć, a więc związać z istniejącą kiedyś rzeczywistością), staje się obecnie swego rodzaju pomostem między dwoma zarysowanymi wyżej tendencjami. $Z$ jednej strony można jej dorobek traktować jako swoisty intelektualny rezerwuar pomysłów, mniej lub bardziej gotowych schematów analizy, czy też konkretnych sposobów rozwiązywania problemów, które wracają w coraz to nowych odsłonach. Dzięki temu potrafi ona dostarczyć ważnych i aktualnych wskazówek, pozwalających zakorzenić nasze myślenie polityczne w żyznym gruncie podobnych naszym, choć minionych, wysiłków poznawczych. Jednocześnie nie unieważnia prymatu teraźniejszości, przyznając się otwarcie do historycznych ograniczeń związanych z rodowodem każdej koncepcji i otwierając tym samym drogę do ich reinterpretacji i wzbogacenia o nowe, bardziej nam odpowiadające wyjaśnienia.

Trudno znaleźć we współczesnej myśli politycznej kierunek, który podążałby wskazaną drogą bardziej konsekwentnie niż tzw. nowi republikanie (neorepublicans, także civic republicans), wśród których najbardziej znane postaci to Quentin Skinner i Philip Pettit. Kymlicka, wyrażając przytoczoną na wstępie opinię o zależności demokracji od właściwie usposobionych w stosunku do niej obywateli, opisuje w dalszej części swej pracy właśnie to środowisko 
i jego idee. Tak Skinner, jak Pettit są przekonani, że powinniśmy raz jeszcze uważnie przeanalizować dorobek myśli politycznej pod kątem wychwycenia niezauważanych dotąd jego odcieni (pierwszy może bardziej niż drugi) oraz zbadać ich ewentualne związki z różnicami stanowisk występującymi obecnie w naszym myśleniu politycznym, by bardziej świadomie wybierać tory, na które chcialibyśmy je skierować (drugi może bardziej niż pierwszy).

Tyle tytułem wprowadzenia, nie jest bowiem celem tego artykułu referowanie poglądów środowiska odpowiedzialnego za współczesny renesans zainteresowania myślą republikańską. Przeciwnie, przedmiotem analizy będą dzieła liczące sobie pół tysiąca lat. Jednak nakreślone powyżej uwagi stanowią istotne tło, na którym trzy przywołane niżej koncepcje będą mogły wyraźniej ukazać niejednoznaczność i wielopoziomowość związków - różnic i podobieństw - które musi przeanalizować każdy, kto pragnie przekonać nas o ciągłości danej tradycji myślenia i rzeczywistym pokrewieństwie twórców do niej zaliczanych. „Powrót do źrodeł” jest w tym przypadku swego rodzaju testem dla współczesnej wersji republikanizmu (i szerzej: dla samej akceptacji swoistego „przepisywania” - czy może raczej ponownego odczytywania, dorobku myśli politycznej), ukierunkowanym nie tyle na jego bezpośrednią analizę i całościową ocenę, ile raczej na ukazanie i zrozumienie tak jego walorów, jak i możliwych ograniczeń; z wykorzystaniem materiału, na którym pracują sami republikanie właśnie. Odwołanie do dawnych myślicieli wprost wyrażających swe poparcie dla tej samej w zarysie ogólnym wizji dobrego państwa, a jednocześnie reprezentujących do pewnego stopnia odmienne ujęcie istoty republiki, osadzone w specyfice własnych krajów, stwarza niepowtarzalną okazję do wszechstronnych porównań i wzajemnych odniesień. Od razu jednak wypada się przyznać, że możliwe obszary takich odniesień zostaną tu przede wszystkim wskazane, nie zaś krytycznie i konkluzywnie przebadane, co wymagałoby znacznie dłuższej pracy.

Ad rem. Za motto posłużyć mogą słowa sir Thomasa Smitha, który po przedstawieniu współczesnego mu systemu społeczno-politycznego Anglii pisze:

„porównajmy go z rzeczamipospolitymi, które aktualnie istnieją, albo też zostały opisane w wiarygodnych źródłach, uwzględniając te materie przede wszystkim, w których różnią się one jedne od drugich, by ujrzeć, kto obrał słuszniejszą, prawdziwszą i wygodniejszą drogę rządzenia narodem, tak w czasie wojny, jak pokoju. Nie będzie to zajęcie błahe dla tego, kto jako Filozof czerpie przyjemność z podobnych dysput, ani też zbyteczne dla tego, kto z własnej woli pragnie służyć Księciu i rzeczpospolitej, wspomagając dobrą radą rządy tegoż”2.

Wprawdzie żadnemu księciu przysłużyć się nie zdołamy, ale chwilowa przemiana w Filozofa zaszkodzić nam nie może. Materiałem do proponowa-

\footnotetext{
${ }^{2}$ T. Smith, De Republica Anglorum, M. Dewar (red.), Cambridge University Press 1982, s. 144.
} 
nych dysput będą trzy prace, pochodzące mniej więcej z tego samego okresu, bo napisane w wieku XVI. Pierwsza - De Republica Anglorum - z której zaczerpnięto wyżej przywołany cytat, to dzieło angielskiego uczonego i dyplomaty, pisane w latach 1562-1565, kiedy Smith przebywał we Francji, jako ambasador Elżbiety I. Drugie dzieło to wyraz zachwytu nad instytucjami Republiki Weneckiej, autorstwa Gasparo Contariniego, także dyplomaty, a przy tym kardynała. I ostatnia praca, z naszego podwórka - choć powstała i opublikowana po raz pierwszy właśnie w Wenecji - Wawrzyńca Goślickiego rozważania $O$ doskonatym senatorze.

Trzy książki, trzy kraje, trzy wizje republiki, trzej wykształceni pisarze o szerokich horyzontach myślowych, a przy tym szczerzy patrioci, przywiązani do swoich państw i przekonani o ich wyjątkowości, zasługującej na to, by mówić o niej głośno i wyraźnie. Wszystko to daje nadzieję, że porównujemy koncepcje równej wagi (i powagi), przemyślane, a przy tym nie stroniące od subiektywizmu, którego zaletą jest konieczność przedstawienia odpowiednio mocnych argumentów na poparcie swych tez. Co ciekawe, każdy z trzech autorów wyraźnie skłania się ku przekonaniu, że to jego ojczyzna stanowi najlepsze ucieleśnienie republikańskiego ideału - i nie jest to przekonanie wyrosłe na podłożu narodowej dumy, ale wniosek, którego mocnym fundamentem ma być cała teoretyczna strona każdego ze wspomnianych dzieł. Stąd rodzi się pytanie, czy dzisiaj, kiedy dystans historyczny zaciera niuanse, a wspólne kategorie pojęciowe (,republika”) skłaniają raczej do eksponowania podobieństw, może mieć znaczenie próba zrozumienia różnic, do których przywiązywali wagę dawni twórcy. I czy te różnice mają jedynie charakter lokalnych urozmaiceń, czy też odzwierciedlają poważniejsze podziały, być może istotne dla głębszego namysłu nad pokrewieństwem (i różnorodnością) tradycji republikańskiej, a także jej związkami z praktyką polityczną konkretnych państw.

Na początek warto choć skrótowo przybliżyć sylwetki trzech wybranych na potrzeby poniższej analizy autorów, zwłaszcza że w ich biografiach znaleźć można wiele interesujących zbieżności, dotyczących między innymi okoliczności powstania głównych dzieł.

Urodzony w 1483 r. Gasparo Contarini ${ }^{3}$ pochodził z rodu o uznanym w Wenecji statusie społecznym i politycznym. Wśród jego przodków znajdowało się między innymi trzech dożów, a on sam po gruntownych studiach w Padwie rozpoczął karierę jako dyplomata. Przebywał na dworze cesarza niemieckiego Karola V w trudnych czasach początków reformacji i wojen chłopskich, podróżując z nim między innymi do Niderlandów i Hiszpanii. Choć zyskał szacunek swego gospodarza (pomimo jego raczej chłodnego sto-

${ }^{3}$ E.G. Gleason, Gasparo Contarini: Venice, Rome and Reform, University of California Press 1993. Informacje biograficzne pochodzą z tej pracy. 
sunku do polityki weneckiej, która zresztą wkrótce miała zmienić sojusznika i oprzeć się na Francji), sam widział w monarchii Habsburgów nie tyle godne tego miana państwo, ile raczej luźny związek krajów połączonych wyłącznie więzami dynastycznymi. Pod tym względem zdecydowanie wyżej cenił mniejszą, ale za to zintegrowaną wokół wspólnych celów, Wenecję. Czteroletnią służbę na dworze Karola V zakończył w sierpniu 1525 r., z ulgą wracając do kraju ${ }^{4}$. Działalności politycznej nie przerwał, uczestnicząc, już jako senator, w najważniejszych dla Wenecji spotkaniach, negocjacjach i porozumieniach. W roku 1535 został mianowany kardynałem przez papieża Pawła III, co było decyzją o tyle nieoczekiwaną, że sam zainteresowany nigdy w życiu nie rozważał i nie podejmował kariery duchownej. Stał się więc swego rodzaju świeckim duchownym, znacznej rangi, bo jednym z głównych kardynałów zaangażowanych w opracowywanie strategii zdolnej przywrócić zachwianą a jak się miało wkrótce okazać, pogrzebaną na wieki - chrześcijańską jedność Europy. Contarini nie szczędził krytyki Kościołowi rzymskiemu, przychylając się do oskarżeń protestantów i domagając się w listach do papieża walki z symonią, nepotyzmem, a nawet tyranią papieskiego dworu. Czynił to na tyle jednoznacznie, że następca Pawła III na tronie Piotrowym, Paweł IV, umieścił jego korespondencję na indeksie ksiąg zakazanych. Mimo takiego afrontu Contarini był do śmierci lojalnym sługą papieża, przekonanym, że religia chrześcijańska powinna nadal znajdować wyraz w jednej i hierarchicznej, tyle że oczyszczonej z błędów, instytucji Kościoła. Zmarł w sierpniu 1542 r., a więc już po zwołaniu przez Pawła III soboru, którego celem miało stać się opracowanie, wyczekiwanej przez Contariniego, reformy (sobór trydencki ostatecznie rozpoczął obrady w $1543 \mathrm{r}$.).

Choć Contarini wypowiadał się zarówno w kwestiach filozoficznych, jak i sprawach Kościoła, największą sławę przyniósł mu pisany około dziesięciu lat i wydany pośmiertnie traktat De magistratibus et republica Venetorum, który do dzisiaj pozostaje najbardziej znanym źródłem wiedzy o ustroju Wenecji tego okresu. Został on opublikowany najpierw po łacinie, w Paryżu w 1543 r. ${ }^{5}$, ale już rok później ukazały się thumaczenia francuskie i włoskie, a w 1599 r. pierwsze tłumaczenie angielskie ${ }^{6}$. Do dziś kwestią sporną wśród badaczy pozostają okoliczności podjęcia tematu przez Contariniego. Jedna z ciekawszych (choć, trzeba przyznać, najsłabiej uargumentowanych) hipotez głosi, że zamysł mógł powstać przy obiedzie, w trakcie debaty jaką od-

${ }^{4}$ Contarini został wybrany na ambasadora we wrześniu 1520 r., ale do Niemiec wyruszył dopiero wiosną $1521 \mathrm{r}$.

${ }^{5}$ De magistratibus et republica Venetorum, libri quinqe, authore Gaspare Contareno Patricio Veneto, Parisiis 1543.

${ }^{6}$ Tłumaczenia na język angielski dokonał L. Lewkenor: G. Contarini, The Commonwealth and Government of Venice, London 1599. Niniejszy artykuł korzysta z poprawionego wydania angielskiego: Amsterdam 1969; oprac. F. Sabetti i P. Mentzel. 
był autor z Tomaszem Morusem w 1521 r., a więc pięć lat po ukazaniu się $U_{t o p i i}{ }^{7}$, którą - niewykluczone - Wenecjanin znał. Bardziej jednak prawdopodobne, że inspiracji Contariniemu dostarczyły raczej rozmowy z ambasadorem Florecji, które łagodziły, jak można się domyślać, tęsknotę obydwu dyplomatów za Italią w czasie ich pobytu na dworze hiszpańskim. Takie wyjaśnienie pozwala lepiej zrozumieć, dlaczego dzieło, mimo niekwestionowanych walorów historycznych, pisane jest zdecydowanie jednostronnie. Jak przyznaje sam Contarini, ma ono przybliżyć cudzoziemcom istotę sukcesu Wenecji, który w oczach autora jest dowodem wielkiej wartości jej ustroju. Co oznacza, że od początku dzieło ukierunkowane jest tak, by przedstawiać wyłącznie pozytywną stronę republiki, a wszelkie podawane fakty interpretować na jej korzyść.

W nieco bardziej powściągliwy sposób stosunek do swojego państwa wyrażał sir Thomas Smith, chociaż i w jego przypadku daje o sobie znać pewna idealizacja angielskiej rzeczywistości politycznej. I tu także nie bez znaczenia jest kontekst powstania książki i pierwsi odbiorcy zawartych w niej myśli. De Republica Anglorum powstawała w latach 1562-1565, a więc w czasie, gdy Smith przebywał we Francji jako wysłannik królowej Elżbiety I. Opisywał instytucje swego kraju z tęsknoty za ojczyzną, jak zwierzał się w liście do jednego z przyjaciół $1^{8}$, dostrzegając coraz wyraźniej odmienność rozwiązań angielskich od starożytnego modelu republiki, a także od państw sobie współczesnych. Dzieło nie przybrało jednak za życia Smitha ostatecznego kształtu - sam autor właściwie więcej o nim nie wspominał - i trudno dzisiaj jednoznacznie stwierdzić, co było tego przyczyną. Zostało wydane po raz pierwszy w roku $1583^{9}$, sześć lat po śmierci Smitha (zmarł w 1577), zyskując uznanie i licznych czytelników (o czym świadczą kolejne wznowienia) ${ }^{10}$. Jak podsumował znany autorytet w dziedzinie historii ustroju Anglii, Frederic Maitland:

${ }^{7}$ T. More, Libellus vere aureus nec minus salutaris quam festiuus de optimo reip. statu, deque nova Insula Utopia, Louvain 1516.

${ }^{8}$ Waltera Haddona; list pisany był pierwotnie po łacinie, a został przetłumaczony na angielski przez L. Alstona we Wprowadzeniu do wydania książki Smitha z 1906 r. List jest cytowany także w wydaniu z roku 1982.

${ }^{9}$ De Republica Anglorum. The maner of governement or policie of the Realme of Englande, compiled by the honorable man Thomas Smyth, Doctor of the civil lawes, Knight, and Principall Secretarie unto the two most worthie Princes, King Edwarde the sixt, and Queene Elizabeth, London 1583.

${ }^{10}$ Jest z tym związany pewien istotny, choć nie do końca jasny fakt - opublikowana wersja traktatu zawiera dłuższy fragment, który jest wiernym powtórzeniem rozdziału pracy Williama Harrisona, opublikowanej w 1577 r. Rodzi to pytania o możliwy plagiat - niekoniecznie dokonany przez Smitha, ale być może przez jego wydawcę. Jako ciekawostkę warto wspomnieć, że sam Harrison potraktował sprawę z fantazją i humorem - w drugim wydaniu swej książki (Description of England, 1587) przytoczył prawie słowo w słowo rozdział z pracy Smitha, otwarcie się do tego przyznając i zaznaczając, że robi to niejako w rewanżu. 
„Nie do pomyślenia jest, by ktokolwiek pisał o Anglii z czasów elżbietańskich bez uwzględnienia tego, co na dany temat zostało napisane przez jej uczonego i utalentowanego sekretarza stanu" 11 .

Nie znaczy to, że gwiazda Smitha zajaśniała dopiero po jego śmierci. Wręcz przeciwnie - należał on do najbardziej prominentnych postaci swoich czasów, nawet jeśli odłożymy na bok, prowadzoną ze zmiennym szczęściem, karierę polityczną ${ }^{12}$. Urodził się w $1513 \mathrm{r}$. w rodzinie hodowcy owiec, a więc członka pomniejszej angielskiej gentry ${ }^{13}$. Wybitne zdolności intelektualne i sprzyjające okoliczności zapewniły mu jednak szybką i spektakularną karierę naukową na Uniwersytecie Cambridge. W wieku lat 14 był już królewskim stypendystą, a 3 lata później rozpoczął nauczanie w Queen's College (jedno z kolegiów Cambridge). Mając lat 20, wykładał grekę, następnie został publicznym oratorem (public orator) uniwersytetu (urząd polegający na przygotowywaniu i wygłaszaniu wszelkich oficjalnych wystąpień w imieniu instytucji), w wieku lat 27 jako Regius Professor objął nowo powstałą katedrę prawa cywilnego, a jako trzydziestolatek został wicekanclerzem ${ }^{14}$. Był doskonałym nauczycielem, jego wykłady (w tym z prawa rzymskiego, które przez półtora roku - tylko! - studiował w Padwie) cieszyły się olbrzymią popularnością. Wiele zdziałał na niwie filologicznej, wprowadzając nową wymowę greki i przyczyniając się do udoskonalania wymowy i pisowni języka angielskiego; nie miał sobie równych także jako wybitny i zaangażowany mówca. Nie sposób pominąć (choć to tylko ciekawostka) nazwiska Smitha także w kontekście sporu o Williama Shakespeare'a. Zdaniem niektórych szekspirologów, w kilku co najmniej dziełach publikowanych pod szyldem „Shakespeare” odnaleźć można wyraźne nawiązania do biografii i osoby Smitha, co ma dowodzić, że ich autorem mógł być, jeśli nie sam Smith (a i takie przypuszczenia są wysuwane) to przynajmniej jego uczeń, Edward de Vere ${ }^{15}$.

Wielkie talenty umysłowe łączył Smith z brakiem ogłady towarzyskiej (do czego sam się przyznawał), bezpośredniością zachowania, a nawet arogancją,

${ }^{11}$ F.W. Maitland, Preface, [w:] T. Smith, De Republica Anglorum, Cambridge 1906.

${ }^{12}$ Smith był przez rok głównym sekretarzem Edwarda VI, nie cieszył się jednak sympatią jego następczyni, Małgorzaty I, kiedy stracił większość piastowanych stanowisk. Do łask wrócił w czasie pierwszych lat panowania jej siostry, Elżbiety I, której głównym sekretarzem był przez 4 lata.

${ }^{13}$ Dane biograficzne pochodzą z pracy: M. Dewar, Sir Thomas Smith: A Tudor Intellectual in Office, London 1964. Pierwszy biograf Smitha, John Strype, nie jest do końca źródłem wiarygodnym - zwłaszcza w przypadku pierwszego okresu jego życia (jego wersja życiorysu jest kompilacją danych dotyczących kilku osób tego nazwiska); por. J. Strype, The Life of the Learned Sir Thomas Smith Kt., Doctor of the Civil Law, Principal Secretary of State to King Edward the Sixth and Queen Elizabeth, New York 1974 (1698).

${ }^{14}$ Kanclerz odpowiada funkcji rektora, ale w przypadku Uniwersytetów Oxford i Cambridge jego znaczenie i ranga były (i są) dużo bardziej prestiżowe niż w polskich uczelniach.

${ }^{15}$ S.H. Hughes, ,, Shakespeare's” tutor: sir Thomas Smith (1513-1577), „The Oxfordian”, vol. III 2000, s. 19-44. 
co komplikowało jego pozycję na dworze - i jak był uwielbiany przez środowisko intelektualne (krąg jego przyjaciół składał się z najwybitniejszych umysłów ówczesnej Anglii), tak nie potrafił się odnaleźć w relacjach politycznych. Tym bardziej że podziały polityczne i różnice stanowisk kształtowały się w kontekście świeżych sporów religijnych, w naturalny sposób zachęcających do radykalizmu. Choć Smith był jednym z pierwszych, którzy poparli protestantyzm, to jednak ekstremistów (tak ze strony nowych anglikanów, jak i papistów) nie znosił, stając się do pewnego stopnia ofiarą własnego umiarkowania. Ale może właśnie dlatego, że mimo chęci i ambicji nie udało mu się odnaleźć dla siebie miejsca w ramach rozgrywek politycznych, utrzymał dystans niezbędny dla zachowania zdolności do chłodnej i całościowej analizy instytucjonalnego porządku własnego państwa.

Wawrzyniec Goślicki herbu Grzymała znany jest dzisiaj jako autor jednego wybitnego dzieła, którego sława po przetłumaczeniu na angielski zawędrowała aż do Nowego Świata ${ }^{16}$. Ale, podobnie jak jego dwaj starsi koledzy po piórze, w czasach sobie współczesnych nie był postacią anonimową. Pochodził ze średniozamożnej szlachty, a dzięki talentom i gruntownemu wykształceniu stał się zarówno ważną osobistością życia politycznego, jak również (co zresztą w ówczesnej Polsce było ze sobą często powiązane) prominentną postacią Kościoła. Rozbieżność wśród biografów co do daty urodzenia Goślickiego sięga lat dziesięciu ${ }^{17}$, ale najczęściej powtarza się tu rok 1530 lub 1533. Studiował sztuki wyzwolone i (prawdopodobnie) teologię w Akademii Krakowskiej, później wyjechał do Padwy i Bolonii, gdzie zyskał tytuł doktora obojga praw. Właśnie we Włoszech (choć dokładne wskazanie miasta i tutaj nastręcza niejakie wątpliwości) powstało dziełko De optimo senatore libri duo ${ }^{18}$, opubli-

${ }^{16}$ Do dzisiaj przedmiotem sporu pozostaje kwestia ewentualnego wpływu dzieła Goślickiego na poglądy Thomasa Jeffersona, a przez to także na amerykańską myśl konstytucyjną i samą konstytucję USA. Hipotezę tego rodzaju sformułował w 1932 r. ambasador RP w USA, Tytus Filipowicz, i choć zrobiła ona sporą karierę, urastając do rangi historyczno-politycznego mitu, nie powinniśmy nadmiernie się do niej przywiązywać. Jak przekonująco argumentuje Teresa Bałuk-Ulewiczowa, z faktu, że w angielskie tłumaczenie De optimo senatore trafiło do Ameryki w żaden sposób nie da się wyciągnąć podobnego wniosku. Staje się on jeszcze bardziej podejrzany po przeczytaniu samego dzieła i próbie znalezienia w nim konkretnych idei mogących służyć Amerykanom jako źródło inspiracji; por. T.J. Bałukówna, Z zagadnień kariery anglosaskiej Wawrzyńca Goślickiego, [w:] Silva rerum series nova, red. T. Ulewicz i W. Berbelicki, Kraków 1981, s. 63-80. Patrz także: T. Bałuk-Ulewiczowa, Wawrzyniec Grzymała Goślicki i jego dzieło „,De optimo senatore”, http:// www.staropolska.pl/renesans/opracowania/Goslicki.html

${ }^{17}$ Fakty z życia Goślickiego podaję na podstawie: O senatorze doskonałym studia, red. A. Stępkowski, Warszawa 2009, a szczególnie w tym zbiorze: A. Stępkowski, Wawrzyniec Grzymała Goślicki: przyczynek do biografii, ibidem, s. 9-34.

${ }^{18}$ Laurentii Grimalii Goslicii, De optimo senatore libri duo in quibus magistratuum officia, civium vita beata, Rerum publicarum foelicitas explicantur, Venetiis 1568 . W artykule wykorzystano najnowsze (dwujęzyczne) wydanie: W.G. Goślicki, O senatorze doskonałym księgi dwie w których sq wyjaśnione obowiązki urzędników oraz szczęśliwe życie obywateli i pomyślność państwa, Kraków 2000. 
kowane po raz pierwszy w Wenecji w 1568 r. Po powrocie do kraju rozpoczął Goślicki karierę polityczną jako sekretarz w kancelarii Zygmunta Augusta (być może pomógł w tym nieco sam traktat, zadedykowany królowi właśnie). Szybko zabłysnął jako zdolny dyplomata, dzięki czemu uczestniczył w najbardziej delikatnych misjach dyplomatycznych, z jakimi miała do czynienia ówczesna Rzeczpospolita. A okazji do wykazania się stanowczością i jednocześnie umiejętnością mediacji i negocjacji nie brakowało - dość uświadomić sobie, że działalność Goślickiego przypadała na okres tak trudny jak czasy pierwszego (a także drugiego i trzeciego) bezkrólewia i walk między pretendentami do nałożenia polskiej korony. Po elekcji Zygmunta III Wazy, Goślickiemu przypadł w udziale zaszczyt wygłoszenia w grudniu 1587 r. mowy powitalnej do nowego króla ${ }^{19}$, która zgodnie okrzyknięta została wzorcowym popisem oratorskim. Był już wówczas biskupem kamienieckim. Kilka lat później objął biskupstwo przemyskie (gdzie aktywnie wspierał zawartą w $1596 \mathrm{r}$. unię brzeską), a w 1601 r. - poznańskie. Choć jeszcze w 1605 r. przemawiał na sejmie przeciwko angażowaniu się w sprawy moskiewskie (słynne dimitriady), były to już ostatnie akordy jego politycznej działalności. Zmarł dwa lata później i został pochowany w katedrze poznańskiej.

Pozycja Goślickiego na dworze królewskim była na tyle mocna, że nie mogły nią zachwiać nawet takie wybory polityczne, jak poparcie Ernesta Habsburga przeciwko Stefanowi Batoremu w staraniach o tron polski, czy też sygnowanie w $1587 \mathrm{r}$. aktu sejmowego potwierdzającego konfederację warszawską (1573). Ten ostatni gest wart jest podkreślenia - nominalne poparcie dla aktu konfederacji oznaczało automatycznie groźbę ekskomuniki i mogło mieć poważne reperkusje dla dalszych losów senatora, dopiero co obdarowanego mitrą biskupią. Kontekstem postawy Goślickiego była groźba destabilizacji państwa w obliczu nieprzejednanego stanowiska w tej sprawie senatorów świeckich (jako biskup reprezentował Goślicki stan duchowny), która spowodowała podjęcie przez niego tak trudnej i z osobistego punktu widzenia niekorzystnej decyzji. To, co zresztą uderza w biografii Goślickiego, to jednoczesne uznanie dla jego kompetencji, potwierdzone znacznym autorytetem, ale nie do końca odzwierciedlone w piastowanych stanowiskach i zaszczytach. Nie udało mu się na przykład (mimo dwukrotnego rozpatrywania tej kandydatury) zostać podkanclerzym koronnym. Także biskupstwo kamienieckie nie było tak wielkim sukcesem, jeśli zważyć, że miało ono najniższą rangę wśród pozostałych, nominacja przyszła stosunkowo późno, a nazwisko Goślickiego wymieniane było wcześniej w kontekście obsady arcybiskupstwa lwowskiego. Trudno wskazać polityczne przyczyny tych pominięć, ale wydają się wiele mówiące o samym Goślickim, którego koncyliacyjny charakter (znajdujący

${ }^{19}$ Witanie Rad i Stanów Koronnych polskich do Króla J. Mści Zygmunta III..., uczynione, [w:] Wybór mów staropolskich, oprac. A. Małecki, Kraków 1860, s. 107-114. 
odbicie tak w poglądach na sylwetkę doskonałego senatora, jak i sukcesach na niwie dyplomacji) nie pozwalał być może na bardziej aktywne i zdecydowane promowanie własnych interesów. Taka samodzielność i swoisty nonkonformizm zresztą, choć motywowane w różny sposób, wydają się być rysem charakterystycznym wszystkich przywołanych tu postaci, a więc także Contariniego i Smitha. Dowodzą one nieprzypadkowości obranego przez nich stanowiska filozoficzno-politycznego, zakorzenionego bardzo mocno w arystotelesowskim ideale praktykowania cnót, który w polityce nakazywał troskę o dobro ogółu oraz mądrość i umiarkowanie w działaniu. Warto zwrócić uwagę na tego rodzaju koherencję myśli i czynu, ponieważ jest ona realnym i możliwym do oceny argumentem przemawiającym za lub przeciw ideom wyrażanym na piśmie, świadcząc o ich spójności i wiarygodności. A jako taka stanowi jeden z wątków wzbogacających refleksję nad myślą polityczną i nadającą jej głębszy wymiar.

Wiek XVI był zresztą ciągle jeszcze stuleciem, w którym wiele tego rodzaju podobieństw wypływało ze specyficznych warunków rzeczywistości społeczno-kulturowej Europy, odziedziczonych po średniowieczu. Jak zauważa George M. Trevelyan:

„Dzisiejsza Europa dzieli się pionowo na szereg oddzielnych państw, każde z nich absolutnie suwerenne na swoim terytorium i każde z nich uważające siebie za reprezentanta pewnej idei etnicznej lub narodowej. Natomiast w średniowieczu Europa była podzielona poziomo na stany i korporacje: duchowieństwa, szlachty, chłopów i mieszczan, które rządziły się lokalnie własnymi swojskimi prawami w swych klasztorach, zamkach, dworach i opasanych murem miastach"20.

Choć pod względem politycznym emancypacja państw narodowych, czyli proces utrwalania i konsolidacji pionowego podziału Europy zaczęła się dużo wcześniej, jedność w warstwie kulturowej trwała zdecydowanie dłużej. Oczywiście niemożliwa i zbędna byłaby próba określenia, jak głęboko sięgały pokrewieństwa, a na ile wyraźne stawały się różnice między poszczególnymi wspólnotami coraz chętniej podkreślającymi swe odrębności. Z pewnością do umacniania świadomości tych ostatnich przyczyniła się reformacja, a później także reforma Kościoła katolickiego, czy też renesansowe zainteresowanie językami narodowymi. Przyczynili się również konkretni ludzie, tacy jak trzej wymienieni, wprawdzie wychowani i wykształceni w ramach ogólnoeuropejskich struktur korporacyjnych, ale myślący już kategoriami nowożytnymi, przedkładającymi ,pionową" solidarność narodową nad „,poziome” związki dynastyczne czy rodowe. Co nie zmienia faktu, że:

„Jedyną dostatecznie potężną siłą do przeprowadzenia rewolucji społecznej w tej skali i o tym ciężarze gatunkowym, była siła państwa narodowego. Wprawdzie

${ }^{20}$ G.M. Trevelyan, Historia Anglii, Wrocław 1965, s. 329. 
despotyzm państwa nakładał na wolność obywateli swoje własne więzy, ale dawał jednostce więcej swobody działania, niż miała w świecie średniowiecznym" ${ }^{\prime 21}$.

Postępowy w swych fundamentach „despotyzm państwa” wkrótce zaowocować miał w większości krajów europejskich całkiem konkretnym despotyzmem władzy królewskiej, której ucieleśnionym symbolem stanie się w wieku XVII klasyczny absolutyzm francuski, a później absolutyzm oświecony w Prusach czy Austrii. W większości krajów, ale nie w Wenecji, nie w Anglii i nie w Polsce, które pod wieloma względami różniły się od swoich sąsiadów. W tej wyjątkowości były przy tym dosyć podobne, choćby z uwagi na fakt, że znajdowały się w dosyć szczególnym punkcie swego rozwoju historycznego.

Opiewana przez Contariniego Najjaśniejsza Republika Wenecji (oficjalnie: Serenisima Repùblica Vèneta), zdawała się w jego czasach świecić pełnym blaskiem ${ }^{22}$. Ukształtowane $\mathrm{w}$ zasadniczych zrębach ustrojowych już w VIII w. państwo (choć formalnie jeszcze przez półtora wieku zależne od Konstantynopola) poczytywało sobie za chlubę nieprzerwaną ciągłość własnych urządzeń republikańskich. Do dziś Wenecja zachowuje tytuł najdłużej istniejącej w dziejach republiki. W 1490 r. ludność Wenecji liczyła 180 tysięcy mieszkańców, co czyniło z niej drugie co do wielkości miasto Europy. Co więcej, nawet posiadający tutaj pierwszeństwo Paryż ustępował jej znacznie pod względem bogactwa. Jak wielu jego współobywateli, Contarini podkreślał niespotykane nigdzie indziej walory swego kraju, który dzięki boskiej Opatrzności powstał w miejscu najdoskonalej zabezpieczonym przed atakiem od strony lądu i morza, a przy tym łatwo dostępnym. Widział w tym przyczynę sukcesu Wenecji i jej awansu do roli naturalnego centrum handlu międzynarodowego. A jednak, jak z perspektywy czasu wskazują historycy - w tym autor monumentalnej Historii Wenecji - już wkrótce po śmierci Contariniego ujawniły się pierwsze symptomy zapowiadające jej zmierzch. Mimo wszystko schyłek ten trwał długo, zważywszy iż definitywnym końcem republiki okazał się dopiero rok 1797, kiedy została ona włączona do monarchii Habsburgów.

Wiek XVI to dla Wenecji duże obciążenie militarne - zmagania z Turcją, w wyniku których republika utraciła wiele ze swych wschodnich posiadłości, a także udział w wojnach włoskich, stanowiących istotny kontekst rywalizacji między Francją a Habsburgami. Okazały się one ważnym sprawdzianem siły wojskowej Wenecji (w tym jej słynnej floty), ale może nawet bardziej - umiejętnej polityki doboru i zmiany sojuszników. Elastyczna polityka międzynarodowa pozwoliła republice ocalić suwerenność, mimo iż zakusy na jej bogactwo czyniono niejednokrotnie, posługując się nie tylko siłami wojsko-

\footnotetext{
${ }^{21}$ Ibidem.

${ }^{22}$ Przytaczane dalej informacje, w tym dane liczbowe, pochodzą z pracy: J.J. Norwich, $A \mathrm{Hi}$ story of Venice, First Vintage Books Edition 1989, s. 390-505.
} 
wymi, ale nawet mocami niebieskimi, jak to w czasie wojny z Ligą z Cambrai (powstałą końcem 1508 r. koalicją antywenecką) uczynił papież Juliusz II, nakładając na Wenecję ekskomunikę. Mniejsze i większe sukcesy polityczne czy wojskowe nie potrafiły zamaskować, a tym bardziej zmienić niekorzystnych procesów historycznych, które wkrótce przypieczętować miały upadek weneckiej potęgi. Do roku 1581 liczba ludności kraju spadła o około jedną trzecią, między innymi w wyniku (nie ostatniej zresztą) epidemii „,czarnej śmierci”. Podobnie, choć w dłuższym okresie, zmniejszała się gospodarcza rola Wenecji, a co za tym idzie, także jej dochody. Po odkryciu Nowego Świata przez Kolumba i odnalezieniu przez Portugalczyków morskiej drogi do Indii, centra handlu międzynarodowego przeniosły się na Zachód Europy.

Lata działalności Thomasa Smitha przypadły na równie wyjątkowy okres w historii Anglii. Urodził się i dorastał w czasach rządów Henryka VIII z nowej dynastii Tudorów ${ }^{23}$, która zasiadła na tronie angielskim w 1485 r., kończąc w ten sposób „wojnę stuletnią” i będącą jej wewnętrznym przedłużeniem „wojnę dwóch róż". Już sam fakt wygaszenia walk obdarzał Tudorów sporym kredytem zaufania. Wprawdzie zmalał on nieco w czasie przepychanek po śmierci Henryka, jak wiadomo posiadającego sześć żon oraz trójkę dzieci, które przeżyły ojca i rościły sobie w związku z tym prawa do tronu. Nie były to jednak kryzysy zagrażające stabilności państwa, a każde z dzieci - kolejno Edward VI (1547-1553), Maria I (lepiej znana jako Bloody Mary - Maria Krwawa, 1553-1558) oraz Elżbieta I (1558-1603) - nałożyło królewską koronę.

W swej Historii Anglii Henryk Zins rozpoczyna opis rządów Tudorów od wiele mówiącego bilansu epoki, będącej świadkiem

„nie tylko poważnego wzmocnienia władzy centralnej i reorganizacji administracji, absolutyzmu królów, reformacji i ważnych przemian w kulturze angielskiej, ale również coraz szerszej ekspansji handlowej szybko bogacącego się kupiectwa angielskiego, awansu klas średnich i politycznego wzrostu Anglii, zwłaszcza od czasu zwycięstwa nad Hiszpanią w 1588 r." ${ }^{24}$.

Każdy element w tym wyliczeniu zasługiwałby na znacznie szersze omówienie, ale wystarczy przytoczyć kilka podstawowych faktów, by potwierdzić opinię, iż pod rządami Tudorów Anglia wydawała się bardziej niż kiedykolwiek w swej historii zdrowa pod względem gospodarczym, silna i pełna optymizmu ${ }^{25}$. Nawet jeśli odrzucimy skrajną tezę, wysuniętą przez je-

${ }^{23}$ Osoby zainteresowane historią Anglii, w tym epoką Tudorów, warto odesłać do pracy w języku polskim: J. Kędzierski, Dzieje Anglii 1485-1939, Wrocław-Warszawa-Kraków-Gdańsk-Lódź 1986.

${ }^{24}$ H. Zins, Historia Anglii, Wrocław 2001, s. 117.

${ }^{25}$ J. Guy, Tudor England, Oxford 1988, s. 32. Ten sam autor opracował znacznie krótsze, a nie mniej ciekawe podsumowanie epoki Tudorów: J. Guy, The Tudors: A Very Short Introduction, Oxford 2000. 
dego z najbardziej liczących się badaczy historii Anglii, Geoffrey'a Eltona, iż już w latach 30. XVI wieku rozpoczęła się zaplanowana przez Henryka VIII i jego głównego doradcę Thomasa Cromwella „rewolucja” w rządzeniu państwem ${ }^{26}$, pozostaje faktem, że jego następcy odziedziczyli usprawnioną machinę państwową, podporządkowaną władcy, stojącemu także od roku $1534^{27}$ na czele nowego Kościoła Anglii. W tej sytuacji panowanie Elżbiety I, znaczone świetnym rozkwitem kultury (,spóźnionym” renesansem), nie bez przyczyny zyskało miano angielskiego ,złotego wieku”. Obrazu dopełniały sukcesy takie jak pokonanie słynnej hiszpańskiej Armady (1588), zapowiadające rodzącą się potęgę angielskiej floty (m.in. królewskich „morskich psów” - Sea Dogs - w rodzaju Francisa Drake'a), czy też dynamiczny rozwój handlu międzynarodowego, umacniający już i tak liczącą się pozycję mieszczaństwa, głównej w tym czasie podpory tronu ${ }^{28}$. A jednak ten sam czas budowy siły społeczeństwa angielskiego, przemian gospodarczych, wreszcie zestrajania nadrzędnej władzy królewskiej z pozostałymi instytucjami życia politycznego (parlamentem, Kościołem anglikańskim) okazać się miał już wkrótce wstępem do poważnych wstrząsów ustrojowych i wojny domowej29.

Po Wenecji i Anglii należałoby w tym miejscu przedstawić rzeczywistość społeczno-polityczną szesnastowiecznej Polski. Jednakże taka prezentacja w przypadku państwa, którego historię znamy, a przynajmniej znać powinniśmy, zakrawałoby z wielu względów na szkolną rozprawkę bez większej wartości poznawczej. Byłoby nietaktem pisanie o rzeczach nazbyt oczywistych, a z kolei przywoływanie istotnych i mniej znanych szczegółów skierowałoby wywód na manowce. Dlatego ograniczmy się do wniosku: także szesnastowieczna Polska przeżywała w czasach panowania Zygmunta I Starego (1467-1548) i jego syna Zygmunta Augusta (1520-1572) okres świetności i swój wiek ,złoty”, zakończony niestety wraz ze śmiercią ostatniego z Jagiellonów i rozpoczynającym się od groteskowych rządów Henryka Walezego okresem spod znaku raz bardziej, raz mniej udanych elekcji viritim. Goślicki, w przeciwieństwie do Smitha i Contariniego, doczekał niespokojnych czasów bezkrólewia i być może wspominał gorzko wcześniejszy optymizm, na fali którego w dedykacji swego dzieła wychwalał nie tylko adresata - króla Zygmunta Augusta - ale i samo państwo polskie, które ,że jest naj-

${ }^{26}$ G.R. Elton, The Tudor Revolution in Government: Administrative Changes in the Reign of Henry VIII, Cambridge 1953.

${ }^{27}$ Data ogłoszenia Aktu Supremacji przez Henryka VIII.

${ }^{28}$ Oczywiście na tym obrazie nie brakowało mniejszych i większych szram, takich jak np. słynna sprawa Marii Stuart. Czytelnicy zainteresowani panowaniem Elżbiety I, oprócz licznych opracowań angielskich, mają także do dyspozycji biografię polskiego autorstwa: S. Grzybowski, Elżbieta Wielka, Wrocław 2009.

${ }^{29} \mathrm{~W}$ dużej mierze w wyniku nieumiejętnej polityki nowej dynastii, Stuartów, których katolicyzm rozniecił, jak się niesłusznie wydawało, wygasły konflikt religijny, a dążenia absolutystyczne wywołały ostrą reakcję reprezentującego społeczeństwo parlamentu. 
sprawiedliwsze potwierdziły zarówno sama rzecz, jak i godne uwagi świadectwa starożytnych" 30 . Pisząc swoje opus magnum był co do tej opinii przekonany. Podobnie jak przekonani o niepowtarzalności swoich krajów byli Smith i Contarini, dostrzegając solidne fundamenty tejże niepowtarzalności w najwyższej próby ustroju republikańskim.

Pojęcie ,republika” jest (i było w wieku XVI) niejednoznaczne, a stosowano je bądź to na określenie państwa w ogóle, jako „licznego zgromadzenia, jednoczonego uznawaniem prawa i pożytków z życia we wspólnocie"31, by zacytować Cycerona, albo też w węższym rozumieniu - traktując republikę jako państwo najlepsze (sprawiedliwe, stabilne, umiarkowane) z uwagi na funkcjonujące $w$ jego ramach rozwiązania ustrojowe. Wszystko przez Arystotelesa, który wykładając cierpliwie zasady najwłaściwszego jego zdaniem ustroju - będącego „mieszaniną” dwóch innych - nie zadał sobie trudu, by wymyślić odpowiednią dla niego nazwę. Pozostał więc przy terminie „politea”, oznaczającym po prostu system polityczny greckiej polis. Słusznie zresztą: w końcu wypaczony system polityczny nie zasługuje na miano państwa w ogóle - ale ku utrapieniu ceniących precyzję historyków doktryn. Utożsamienie politei z formą ustroju mieszanego wykorzystał następnie Polibiusz, snując rozważania o ustroju Republiki Rzymskiej („res publica” - „rzecz publiczna” oznaczała, podobnie jak w Grecji, państwo). Tak dwuznaczność zagościła również w języku łacińskim i kontynuowała swą karierę dzięki kolejnym myślicielom politycznym, poszukującym właściwego modelu ustrojowego dla swych wspólnot. W myśl założeń Arystotelesa, przywiązanego do zasady ,złotego środka”, politea miała być zmieszaniem demokracji i oligarchii - a nawet nie tyle tych dwóch ustrojów, ile leżących u ich podstaw zasad. Mechaniczne mieszanie demokracji i oligarchii nie miałoby dla Stagiryty większego sensu, ponieważ były to ustroje złe; z uwagi na swą jednostronność przeczące umiarowi w korzystaniu ze skądinąd pożytecznych zasad: wolności i majątku. Inaczej, bo właśnie „dodając” instytucje ustrojów czystych, tworzył zręby ustroju mieszanego Polibiusz, który mógł sobie na taki krok pozwolić, ponieważ mieszał wyłącznie ustroje dobre. I właśnie Polibiuszowski koncept złożenia monarchii, arystokracji i demokracji - którego wiernej realizacji upatrywał sam autor w modelu ustrojowym Rzymu - zyskał uznanie rodowitych rzymskich piewców republiki ${ }^{32}$, m.in. najlepiej nam znanego Cycerona.

Zainteresowanie tradycją republikańską odrodziło się wraz z renesansem, nie tylko w wyniku powrotu do starożytności, ale także z powodu poszukiwań nowej teorii politycznej, zdolnej wesprzeć emancypację monarchii na-

${ }^{30} \mathrm{~W}$. Goślicki, op. cit., s. 7.

${ }^{31}$ M.T. Cyceron, O państwie. O prawach, spolszczyła I. Żółtowska, Kęty 1999, s. 26.

32 Polibiusz był Grekiem. Przebywał w Rzymie najpierw jako niewolnik, ale szybko zyskał sympatię i szacunek swego właściciela, a ostatecznie i wolność. 
rodowych. Jak wiemy, prawo rzymskie okazało się tutaj nieocenioną pomocą; podobnie zdaniem wielu pomóc mogła koncepcja republiki, jako państwa umocowanego w zgodnej woli obywateli i służącego ich dobru. Choć nie zaprzeczano arystotelejskim źródłom całej koncepcji, chętniej sięgano po inspiracje rzymskie, a to $\mathrm{z}$ racji bezpośredniego odwołania do monarchii, która - tak jak arystokracja - była dla Arystotelesa odrębną formą ustrojową ${ }^{33}$.

Contarini, Goślicki i Smith podążają tą właśnie drogą. Własne państwa są dla nich przykładem wspólnot wiernie realizujących republikański ideał. W wielu punktach ich koncepcje stanowią powtórzenie rozważań Arystotelesa i Cycerona, w wielu innych wyprowadzane wnioski wskazują, że opierając się na wcześniejszym dorobku myśli politycznej, nie boją się myśleć samodzielnie i wykraczać poza schematy starożytne, by uwzględnić i wyeksponować poglądy, na których zależy im najbardziej tak z racji historycznych, jak i patriotycznych. W tej perspektywie trzy wizje republiki tworzą uzupełniającą się całość, pozwalającą nakreślić najważniejsze dla republikanizmu przekonania i tezy. I choć nie tracą swej specyfiki, która jest tutaj punktem wyjścia, stapiają się ostatecznie w jedno wielkie dzieło - już nie opis republiki weneckiej czy angielskiej, ale po prostu ,republiki” tout court. Jest jednak możliwe także nieco inne spojrzenie, i ono będzie tu wykorzystane. Chodzi mianowicie o drogę przeciwną; wychodzącą od założenia ideowego pokrewieństwa i komplementarności wszystkich trzech koncepcji, ale poszukującą ewentualnych „rozdroży”, czyli miejsc od których zaczynają one podążać wytyczonym przez siebie szlakiem. O jednym z takich interesujących rozdroży i jego konsekwencjach dla myślenia republikańskiego będzie teraz mowa.

Jeśli mielibyśmy wskazać słowa, które najczęściej przewijają się na kartach przywoływanych dzieł, nie byłoby nadużyciem wymienienie następujących: prawo, instytucje i cnota. Trzej autorzy szermują nimi wyjątkowo często, udowadniając, że właśnie te trzy kategorie są najbardziej charakterystycznymi składowymi właściwie urządzonej republiki. Rozumieją je zresztą tak samo. Prawo to wydoskonalony i niemal boski rozum, pozbawiony namiętności i afektów, jak tłumaczy, powołując się wprost na Arystotelesa, Con-

${ }^{33}$ Warto wspomnieć również o upowszechnionej wówczas, nieco odmiennej interpretacji terminu ,republika”, która wyłania się z pism Niccolò Machiavellego. Trzy grosze, które wtrącił autor Księcia do debaty nad republiką są, zdaniem wielu badaczy, swoistym przełomem, odpowiedzialnym za jej nowożytne (także nasze współczene rozumienie). Machiavelli bowiem dzieli wszystkie państwa na monarchie i republiki. Jeśli jednak mamy tu do czynienia z przełomem, to jego waga stała się widoczna znacznie później, głównie za sprawą Karola Monteskiusza. Sam Machiavelli nie wgłębiał się w teoretyczne podstawy typologii ustrojów, a widoczna w jego myśli rewizja pojęcia republiki jest przede wszystkim konsekwencją odrzucenia - kluczowego dla Arystotelesa - podziału ustrojów na „,dobre” i ,złe”. O ile według Arystotelesa dążenie do dobra ogółu (politei) da się odróżnić od realizacji interesów rządzących i to stanowi kryterium podziału form ustrojowych, o tyle według Machiavellego rządzący zawsze działają w swoim interesie, tyle tylko że ich interes jest zarazem interesem państwa. W ten sposób jedynym kryterium różnicującym ustroje pozostaje liczba osób sprawujących władzę, a konkretnie różnica między rządami jednostki i rządami wielu. 
tarini ${ }^{34}$. Wtóruje mu Smith, określając tworzone prawo jako święte (sanctum). Sam kładzie jednak nacisk na poprzedzającą prawo zgodę obywateli, wypracowaną $\mathrm{w}$ ramach republikańskich instytucji ${ }^{35}$. Popiera szacunek wobec instytucji Goślicki, wskazując, iż połączenie zalet monarchii, arystokracji i demokracji w ramach jednego ustroju, nadaje mu większą stabilność i trwałość. Dodaje jednak - i przytakują mu koledzy po piórze - że największą zaletą republiki jest wykorzystanie w stopniu maksymalnym cnotliwości obywateli ${ }^{36}$ : ich mądrości, aktywności i zaangażowania politycznego.

Bez wątpienia trzej myśliciele podają sobie dłonie, zgodnie przyznając prawu, instytucjom i cnocie decydujący wpływ na kształtowanie rzeczywistości republikańskiego państwa. Ale kiedy przejrzymy ich dzieła pod kątem wzajemnych zależności między tymi elementami, napotkamy pewną interesującą prawidłowość. Każdy z nich akcentuje bowiem inny z nich, czyniąc go fundamentem dla dwóch pozostałych.

Pisze Contarini:

„choć jest oczywiste, że istniało wiele wspólnot, znacznie przewyższających Wenecję tak w potędze i posiadłościach, jak w sile militarnej i chwale wojennej; to jednak nie było żadnej mogącej się z nią równać z uwagi na instytucje i prawa roztropnie nadane" ${ }^{\prime 37}$.

I dodaje:

„Niejednokrotnie zjawiali się w Atenach, Sparcie i Rzymie niezwykli i cnotliwi mężowie wyjątkowych zasług, pełni oddania swemu krajowi, ale tak niewielu, że odrzuceni przez większość nie byli w stanie w pełni wykorzystać swych cnót. Ale nasi przodkowie, po których odziedziczyliśmy tak kwitnącą republikę, wszyscy razem zjednoczyli swe wysiłki w zgodnym pragnieniu ustanowienia, poszanowania, i wzmocnienia swego państwa, bez najmniejszego względu na swą własną chwałę czy wygodę"38.

Fragment oddający hołd mądrości i bezinteresowności przodków nie jest w ustach Contariniego przypadkowym peanem na cześć. Oprócz, zapewne szczerego, przekonania o ich wyjątkowej prawości, Contarini potrzebuje tejże prawości w celach teoretycznych. Nawiązanie do wysokiej próby źródeł prawa pozwala Contariniemu ufundować aktualny porządek prawny w mądrości i uniwersalnych zasadach sprawiedliwości, a nawet otoczyć nimbem swo-

${ }^{34}$ G. Contarini, op. cit., s. 42.

${ }^{35}$ T. Smith, op. cit., s. 78.

${ }^{36}$ Już w dedykacji dzieła Goślicki deklaruje, że skłania się ku tym myślicielom, którzy twierdzą, że szczęście państwa i obywateli „mogłoby (...) stać się dziełem doskonałym królów, gdyby obywatele naśladowali ich cnoty i zupełnie się do nich upodobnili”; W. Goślicki, op. cit., s. 3.

${ }^{37}$ G. Contarini, op. cit., s. 36.

${ }^{38}$ Ibidem. 
istej boskości i nienaruszalności. Im większa przepaść między obywatelami a uświęconymi wielowiekową tradycją regułami, tym większy autorytet tych ostatnich i większa stabilność państwa. Argumentacja Contariniego roztacza przed naszymi oczami wizję republiki, której prawo jest wcieleniem najwyższej cnoty (mądrości) i z tej racji wzbudza w obywatelach naturalny szacunek i podziw, zdolny skłonić ich do zgodnego współdziałania i pracy na rzecz dobra wspólnego.

Od początku Contarini pragnie wyeksponować prawo, jako główny element odpowiedzialny za sukces weneckich instytucji republikańskich. Jak władzę nad owcami sprawuje pasterz, a nie samo stado, tak też człowiek powinien być rządzony przez pierwiastek wyższy i doskonalszy niż on sam ${ }^{39}$. Problem polega jednak na tym, że w świecie niczego doskonalszego od człowieka znaleźć nie sposób, a on sam jest istotą nazbyt ułomną, by zdawać się w swym postępowaniu na własny osąd. Dlatego musi uznać wyższość prawa, zdolnego uporządkować relacje społeczno-polityczne na tyle skutecznie, by zapewnić trwałość, ale i elastyczność całego systemu.

W myśl tej koncepcji prawo - rozumiane szeroko, jako wszelkie reguły normujące zachowania i relacje interpersonalne w sferze publicznej - staje się głównym czynnikiem odpowiedzialnym za konstrukcję właściwego porządku republikańskiego, którego dopełnieniem są dopiero konkretne instytucje życia politycznego oraz odpowiednio wychowywani obywatele. Nic dziwnego, że opisując w swoim dziele instytucje Wenecji, Contarini kładzie nacisk przede wszystkim na procedury powoływania ich członków, wzajemne relacje oraz sposoby głosowania, zapobiegające korupcji systemu politycznego. Jest to lektura pouczająca nie tylko z uwagi na szczegółowość opisu, ale również dostrzegalny zachwyt autora nad związkiem między najdrobniejszymi nawet przepisami a funkcjonowaniem państwa. Można wręcz odnieść wrażenie, że pomyślność Wenecji wypływała bezpośrednio z przestrzegania żmudnych i długotrwałych procedur losowania ${ }^{40}$ niższych urzędników, a nawet związana była z liczbą i kolorem kulek wrzucanych do naczyń przy okazji podejmowania niektórych decyzji.

Opinia taka nie jest przejawem ironii. Według Contariniego właśnie drobiazgowa regulacja prawna całej sfery politycznej nadaje państwu trwałą strukturę, stając się szkieletem dla realizowania republikańskich wartości. Prawo tworzy system władz republiki, przypominający swego rodzaju piramidę - z Wielką Radą ${ }^{41}$ u podstawy, wybieranym przez nią Senatem, Radą

${ }^{39}$ Ibidem, op. cit., s. 40.

${ }^{40}$ Losowanie było powodem dumy Wenecjan i dowodem, iż system polityczny wykorzystuje elementy rządu ludowego, czyli demokracji, która respektuje równość obywateli w sferze publicznej. Podkreśla to także wielokrotnie Contarini (op. cit., s. 61).

${ }^{41}$ Wł. Maggior Consiglio - instytucja, która z czasem przejęła kompetencje zgromadzenia ludowego (Arengo), licząca 480 członków rekrutujących się spośród członków rodów arystokratycz- 
Czterdziestu (Quarantia) pełniącą funkcje sądownicze, Radą Dziesięciu, Małą Radą (Minor Consiglio) i obdarzonym największym autorytetem dożą ${ }^{42}$. Im węższe ciało, tym reguły określające jego pozycję bardziej ogólne, pozwalające piastującym je osobom na podejmowanie samodzielnych decyzji - ale przebycie drogi na szczyt piramidy mogło nastąpić tylko po wcześniejszym przyzwyczajeniu jednostki do sprawiedliwego (zgodnego z prawem) postępowania na niższych szczeblach władzy. Obowiązek respektowania republikańskiego porządku miał obowiązywać wszystkich bez wyjątku: obywateli skłonnych słuchać podszeptów nadmiernych ambicji straszył czarny woal w szeregu portretów weneckich dożów - zasłaniający obraz Marino Faliero, ściętego w 1355 r. z rozkazu Rady Dziesięciu. Prawo mogło dosięgnąć każdego, co najlepiej świadczyło o jego zwierzchności ${ }^{43}$.

Nie bez powodu obywatele po ukończeniu 20. roku życia, jeszcze przed nabyciem pełni praw politycznych ${ }^{44}$, kierowani byli do adwokatury, gdzie mieli obserwować i uczestniczyć w pracach polegających na „obronie praw”45. Następnie stawali się członkami Wielkiej Rady, której głównym zadaniem było przeprowadzanie i pilnowanie procedur elekcyjnych. Tak ważna w myśli republikańskiej cnotliwość jednostek sprowadzała się w tym przypadku przede wszystkim do zaangażowanego wypełniania przypisanej do każdego poziomu władzy roli; czyli de facto do naśladownictwa ustalonych wzorców. Ważny dla Contariniego - i również wprowadzony przez przewidujących przodków - był obyczaj częstych spotkań Wielkiej Rady, podtrzymujący „jedność i miłość” w ramach wspólnoty ${ }^{46}$. Oczywiście trzeba zaznaczyć, że rzeczona jedność dotyczyć miała wyłącznie sfery politycznej. Jak zauważają współcześni badacze, ustanowienie tej sfery było owocem swoistego kompromisu między społeczeństwem, wyraźnie już ukształtowanym przez nowo-

nych wpisanych do tzw. Złotej Księgi (Libro d'oro), liczącej w czasach Contariniego ok. 200 rodów. Tylko tej grupie przysługiwała pełnia praw politycznych i spośród nich rekrutowali się urzędnicy wyższego szczebla, łącznie z dożą. Status obywatela (choć o ograniczonych prawach politycznych) przysługiwał także potomkom pierwszych osadników weneckich, którzy jako Cittadini Originarii wpisani byli do Srebnej Księgi (Libro d'argento). Powstanie obu ksiąg wiąże się z pierwszym ,zamknięciem" Wielkiej Rady - ograniczeniem jej składu - w 1. 1297-1323. O przynależności do arystokracji decydowało więc urodzenie, ale nie była to elita zupełnie zamknięta przed reprezentantami Originarii. Należy także pamiętać, że arystokracja wenecka przypominała pod względem zajęć i wartości zachodnioeuropejskie mieszczaństwo. Interesujący opis społeczeństwa Wenecji znaleźć można w pracy: S. Chojnacki, Women and Men in Renaissance Venice: Twelve Essays on Patrician Society, Baltimore 2000.

42 Opis skomplikowanego systemu politycznego Wenecji znaleźć można m.in. w pracy: G. Cozzi, Authority and the Law in Renaissance Venice, [w:] Renaissance Venice, red. J.R. Hale, London 1973, s. 293-345.

${ }^{43}$ G. Contarini, op. cit., s. 102.

${ }^{44}$ Automatycznie od 25. roku życia, ale Wielka Rada mogła przyjmować także młodszych, a już zasłużonych obywateli.

${ }^{45}$ G. Contarini, op. cit., s. 48.

${ }^{46}$ Ibidem, s. 50-51. 
żytny indywidualizm i odległym od dominujących na kontynencie wzorców średniowiecznych ${ }^{47}$.

Podobnie nowożytny charakter miało społeczeństwo Anglii. I, jak w przypadku Contariniego, zauważyć można u Smitha poszukiwanie czynnika, który pozwoliłby - bez blokowania indywidualnej aktywności obywateli, ożywionych renesansową wiarą we własne siły - ustanowić podstawy tego, co wspólne: rzeczypospolitej właśnie. Dla Smitha punktem wyjścia i bazą republiki są jednak ukształtowane w procesie historycznym instytucje życia społecznego, nie prawo. To ostatnie, choć ważne, musi być dostosowane do konkretnego społeczeństwa, jak „odzienie” czy „,but”, który „,jeśli jest za mały lub za duży na stopę, będzie ranił i uwierał" "48. Anglia jest słusznie określana monarchią, ale to nie zmieniało, zdaniem Smitha, republikańskiej istoty jej ustroju, potwierdzanej przez co najmniej dwie cechy. Po pierwsze, autorytet króla wyrastał z wzajemnej zgody wolnych obywateli ${ }^{49}$. Po drugie, obywateli traktowano od początku jako podmioty życia politycznego, uczestniczące we współrządzeniu państwem. Mało które państwo zresztą, według Smitha, realizuje „czysty” model ustrojowy - zdecydowanie częściej, jeśli nie zawsze, mamy do czynienia $\mathrm{z}$ ustrojem mieszanym, dla uproszczenia nazywanym „monarchią”, ,arystokracją” lub „demokracjąa” od elementu, który przeważa $^{50}$. Uzyskanie jedności, niezbędnej w sferze politycznej, jest w ustroju mieszanym trudniejsze, gdyż wymaga zrównoważenia i współdziałania aż trzech różnych składowych. Stąd istotna rola kształtu instytucjonalnego państwa, pozwalającego zachować stabilne struktury, w których możliwe będzie zachowanie spójności państwa, ale i zaspokojenie aspiracji dynamicznie rozwijającego się społeczeństwa.

Instytucjonalnego charakteru nabierają dla Smitha nawet podziały społeczne, do których przywiązuje on szczególną wagę. Dzięki tej głębszej podstawie instytucje centralne w naturalny sposób stają się emanacją społeczeństwa $^{51}$, umacniając poczucie wspólnotowości. Wskazuje Smith cztery grupy obywateli, przy czym najniższa z nich (w tym drobni rolnicy i rzemieślnicy) pod względem uczestnictwa politycznego jest zdecydowanie upośledzona choć uwypukla autor jej rolę w ramach lokalnych wspólnot, tak miejskich jak i wiejskich ${ }^{52}$. Rzeczywisty udział w rządzeniu państwem mają członkowie

${ }^{47}$ Związek między praktyką społeczną a ideałami republikańskimi nie był oczywiście prosty i jednoznaczny. Interesująco przedstawia go Edward Muir; patrz: E. Muir, Was There Republicanism in Renaissance Republics? Venice after Agnadello, [w:] Venice Reconsidered: The History and Civilization of an Italian City-State, 1297-1797, red. J.J. Martin, D. Dennis, Baltimore 2000, s. 137-167.

${ }^{48}$ T. Smith, op. cit., s. 63.

${ }^{49}$ Ibidem, s. 59.

${ }^{50}$ Ibidem, s. 52.

${ }^{51} \mathrm{~W}$ interesujący sposób ten związek opisuje Michael J. Braddick; patrz: M.J. Braddick, State Formation in Early Modern England, c. 1550-1700, Cambridge 2000.

${ }^{52}$ Ibidem, s. 76-77. 
pozostałych trzech grup obywateli, choć oczywiście różni ich zakres posiadanych uprawnień. Są to: szlachta, na czele z królem lub królową, mieszczanie, czyli członkowie nowej angielskiej gentry oraz tzw. yoemeni (chłopi, dzierżawcy, drobni posiadacze ziemscy zobowiązani do służby wojskowej). Nie bez znaczenia wydaje się nacisk, jaki kładzie Smith na instytucjonalny charakter podziałów społecznych - przynależność do określonej grupy społecznej nie tyle ma stygmatyzować jednostkę, ile wskazywać przez nią pożądany sposób wypełniania określonej społecznej roli. Można tak wnioskować na podstawie szczegółowych wyjaśnień Smitha dotyczących sposobów awansu społecznego i obrony otwartej (w porównaniu z rozwiązaniami znanymi z innych krajów) struktury społeczeństwa. Jednostki, które z uwagi na swoje zasługi, starania, cechy osobiste przewyższają wymagania pełnionej roli, mogą poprawić swój społeczny status. Pisze Smith:

„nie ma w tym nic nieodpowiedniego. Bo po pierwsze władca nic na tym nie traci, jak traciłby, gdyby to miało miejsce we Francji53: ponieważ gospodarze czy chłopi nie podlegają w Anglii podatkom większym niż gentlemeni: nie, co do obciążeń na rzecz króla od gentlemana wymaga się więcej (...)"54.

Stabilna ma być, zdaniem autora De Republica Anglorum, struktura instytucjonalna organizująca społeczeństwo, ale nie ono samo. Jest to różnica subtelna, ale zasadnicza, pozwala bowiem odróżnić obywatela - konkretne indywiduum - od pełnionej przez nią roli w porządku społecznym. Oceniana i weryfikowana jest ta ostatnia, co umożliwiało dosyć elastyczny stosunek do tych cech jednostek, które nie miały z nią związku. Takie podejście pozwoliło na przykład Smithowi bez szerszego komentarza przyjąć, iż urząd królewski może sprawować tak król, jak i królowa ${ }^{55}$, choć prawa kobiet do tronu były kwestionowane i odrzucane choćby przez Francuzów, a więc pierwszych potencjalnych odbiorców jego dzieła. Prymat instytucji prowokował koncentrację przede wszystkim na zewnętrznych regułach zachowania, świadczących o zrozumieniu i wypełnianiu obowiązków społecznych. Niebagatelna jest w tym kontekście uwaga Smitha, wskazująca, iż osoba zajmująca wyższą pozycję w społeczeństwie „musi otwierać swą kiesę szerzej (...) bo w przeciwnym razie naraża na szwank swą reputację"56. Tak więc jednostki mogą i powinny rozwijać aktywność z nadzieją na polepszenie swej kondycji społecznej, ale jednocześnie pamiętać muszą o rosnących wówczas wobec nich oczekiwaniach ze strony całej wspólnoty. To zachęca do roztropności i umiar-

${ }^{53}$ We Francji głównym źródłem dochodów państwa był podatek gruntowy (la taille), od którego szlachta była zwolniona.

${ }^{54}$ T. Smith, op. cit., s. 72.

${ }^{55}$ Ibidem, s. 65.

${ }^{56}$ Ibidem, s. 72. 
kowania, niezbędnych do osiągnięcia dwóch rzeczy stanowiących cel ludzkich dążeń: własnych korzyści i honoru ${ }^{57}$.

Skoro podstawą republiki są jej instytucje, zachowanie porządku publicznego wymaga ich spójności i zgodnego współdziałania. Dla Smitha wyrazem obydwu i dowodem trwałości republiki angielskiej jest współpraca między królem a parlamentem ${ }^{58}$, reprezentującym tak szlachtę (Izba Lordów), jak i lud (Izba Gmin). Stąd szczegółowy opis procedur legislacyjnych, w których każdy krok ma potwierdzać, że stanowione prawo jest wyrazem wzajemnej i powszechnej zgody obywateli, domniemanej na podstawie zgody ich reprezentantów ${ }^{59}$. Można odnieść wrażenie, że ten ostatni element jest dla autora ważniejszy niż samo prawo - liczy się przede wszystkim demonstracja zgodnej woli obywateli, umocowanej w dzielonych przez nich wartościach, wykształconych przez instytucje obyczajach, wreszcie szanowanej ogólnie tradycji. „To, co ustanowione w wyniku tej zgody - dodaje Smith - nazywamy wiążącym, trwałym, i świętym, i jest uważane za prawo"60.

Stanowisko Contariniego i Smitha w kwestii najsolidniejszego fundamentu republikańskiego porządku można podsumować ostrzeżeniem tego pierwszego, iż sami, najlepsi nawet obywatele nie wystarczą do urządzenia dobrego państwa i we wspólnocie ludzkiej musi „znaleźć się coś bardziej boskiego, czemu powinno powierzyć się rządy”61. Tym „czymś” jest dla Contariniego prawo, a dla Smitha instytucje, które to elementy pozwalają ,zobiektywizować" państwo, będące, zgodnie z teorią republikańską, własnością obywateli. $\mathrm{W}$ ten sposób to, co wspólne staje się namacalne i zrozumiałe dla wszystkich, narzucając warunki działania w sferze publicznej. Ma to dwie, uzupełniające się zalety. Po pierwsze, republika utrwalona przez prawo i instytucje zmniejsza odpowiedzialność poszczególnych jednostek za realizację dobra wspólnego (niwelując także ich możliwy brak kompetencji w tej dziedzinie). Po drugie, zmniejszenie politycznej roli jednostek, pozwala im na większą aktywność w innych dziedzinach, a więc wzmacnia indywidualizm i wolność. Tak więc powyższe rozwiązanie służy i całej wspólnocie i wszystkim jej członkom z osobna. Można mu jednak postawić pewien zarzut natury teore-

${ }^{57}$ Ibidem, s. 62.

58 Zdaniem niektórych autorów - zwłaszcza poszukujących doktrynalnych początków konfliktu między królem a parlamentem angielskim - przeciwko takiej interpretacji świadczy pierwsze zdanie II Księgi pracy Smitha: „Najwyższa i absolutna władza w królestwie Anglii spoczywa w Parlamencie” (s. 78). Nie chcą oni jednak pamiętać, że kilka stron dalej, po opisie wielu ,absolutnych” uprawnień królewskich, spotkać można i takie zdanie: „Podsumowując, władca jest życiem, głową i autorytetem dla wszystkiego, cokolwiek dzieje się w królestwie Anglii” (s. 88); patrz np.: P.C. Herman, Royal Poetrie: Monarchic Verse and the Political Imaginary of Early Modern England, Cornell University Press 2010, s. 136-137.

59 Ibidem, s. 78-88.

${ }^{60}$ Ibidem, s. 78.

${ }^{61}$ G. Contarini, op. cit., s. 40. 
tycznej - zwolennicy tej opcji zdają się sugerować, że jest w gruncie rzeczy możliwe funkcjonowanie dobrej republiki nawet w przypadku deficytu ,,prawdziwych" republikanów, wiernych cnocie i troszczących się bardziej o dobro wspólne niż własny interes. Zresztą mimo całej sympatii wobec potencjału intelektualnego i cnotliwości obywateli, przyznają sami republikanie, że każdy - nawet najbardziej cnotliwy - człowiek jest narażony na chwile słabości i uleganie namiętnościom ${ }^{62}$. Muszą one zostać poskromione, zanim sięgną sfery politycznej i zaczną wywierać wpływ na losy całej wspólnoty. Podejście takie dowodzi realizmu politycznego wyglądającego spoza republikańskich ideałów, a jednocześnie nowożytnego postrzegania państwa jako instytucji o publiczno-prawnym charakterze, odrębnym od tworzących go jednostek.

$\mathrm{Na}$ takim tle wersja republikanizmu prezentowana przez Goślickiego a można by nawet zaryzykować tezę: prezentowana przez większość polskich republikanów w całym okresie trwania I Rzeczypospolitej - ma zdecydowanie bardziej radykalny charakter. Punktem wyjścia jest tutaj trzeci z wymienionych na początku składowych republiki: indywidualna cnota. Dopiero jej rządy gwarantować mają tak rozumność prawa, jak prawidłowe funkcjonowanie instytucji życia publicznego. Zmianę perspektywy można zauważyć już na początku dzieła, w dłuższym fragmencie, z którego warto zacytować kilka zdań:

„Jak bowiem bydlęta nie mogą być strzeżone i kierowane same przez siebie, bez żadnego pasterza człowieka, tak i ludzie nie mogą być dobrze rządzeni przez ludzi, bez kierownictwa Boga. (...) W jaki zaś sposób należy prosić Boga o wskazówki rządzenia państwem? (...) Zresztą, Bóg jest przy mądrych, jest w nich (...). Dobry staje się Bogiem i mądry nie żyje bez Boga, jest przewidujący, bystry, zaradny, do podobieństwa do Boga dochodzi przez własną cnotę, która wywodzi się od prawdziwego rozumu"63.

Odwołanie do „bydląt i pasterza” pojawiło się już wcześniej - zastosował je do wyjaśnienia założeń swej koncepcji także Contarini. Obydwaj myśliciele znają i uznają nauczanie starożytnych ${ }^{64}$, ale jako twórczy uczniowie, rozumieją je i interpretują w charakterystyczny dla siebie sposób. Contarini używa rzeczonej metafory, by z tezy o braku w tym świecie czegoś doskonalszego od człowieka postawić na czele rzeczypospolitej prawo - racjonalne i niezależne od jednostkowych wzlotów i upadków. Goślicki wprawdzie zgadza się z Wencjaninem co do konieczności oparcia rządów o pierwiastek „wyższy”, ale poszukuje go nadal w jednostce:

${ }^{62}$ G. Contarini, op. cit., s. 42.

${ }^{63}$ W. Goślicki, op. cit., s. 19-23.

${ }^{64}$ Przykład „bydląt” i „,pasterza” pojawia się choćby w Państwie Platona, w wywodzie Sokratesa poświęconym sprawieliwości rządzących; por. Platon, Państwo. Prawa, tłum. W. Witwicki, Kęty 2001. 
„Człowiek ten, który będzie znał siebie, zrozumie, że wszystko ma w sobie boskie i będzie uważał myśl i rozum w sobie za jakieś boskie odbicie i dzięki tak wielkiemu dobrodziejstwu bożemu, zawsze będzie coś godnego myślał albo czynił"65.

Pomyślność rzeczypospolitej bezpośrednio zależy tutaj od obywateli, ich indywidualnej wartości i cnotliwości. Więcej: dzięki uznaniu cnoty za punkt wyjścia w opisie właściwego porządku państwowego, Rzeczpospolita w najgłębszym, normatywnym sensie, rezyduje w umysłach i sercach ich samych.

Ostatnie twierdzenie to nie tylko pełna egzaltacji figura retoryczna - a za taką uważa się często podobne w wymowie wypowiedzi piewców szlacheckiego republikanizmu XVI i XVII w. Nie jest to także wyraz idealistycznego stosunku do polityki (w znaczeniu: bagatelizującego rzeczywiste relacje władzy); jako że idealizm, który zaczyna wywierać determinujący wpływ na praktykę polityczną i staje się zrozumiałym przez wszystkich uczestników życia publicznego sposobem artykulacji własnych interesów, przestaje być idealizmem. $Z$ taką zaś sytuacją mamy tutaj do czynienia. I choć wiarygodne uzasadnienie powyższego przekonania wymagałoby odrębnego artykułu, warto zwrócić uwagę na kilka faktów, które mogłyby wskazać drogę dalszych poszukiwań specyfiki polskiej myśli republikańskiej na tle innych jej odmian narodowych ${ }^{66}$.

Na tle Wenecji i Anglii, Polskę wyróżniała liczebność i prawne uprzywilejowanie szlachty, wpływające na kształt naszego parlamentaryzmu. Nie było w Europie państwa, w którym aż 10\% społeczeństwa rościłoby sobie pretensje do czynnego udziału w życiu politycznym. Zamknięcie stanu szlacheckiego, potwierdzane kolejnymi przywilejami, utożsamiło z czasem pojęcie obywatela i szlachcica, który szczycił się często wyłącznie genealogią, jako że prawa polityczne nie uwzględniały statusu majątkowego (problem szlachty „gołoty”). Od strony pokrewieństw doktrynalnych, pewnego sposobu myślenia o państwie i jego obywatelach, nie bezzasadne jest określanie Rzeczypospolitej mianem demokracji szlacheckiej ${ }^{67}$; ideologia szlachty przypominała bowiem postrzeganie instytucji państwa jako związku obywateli, charakterystyczne dla małej greckiej polis. Podobnie jak opiewana przez Peryklesa ${ }^{68}$ demokracja ateńska, I Rzeczpospolita miała być realizacją zasad równości,

${ }^{65}$ W. Goślicki, op. cit., s. 19.

${ }^{66}$ Osobom zainteresowanym takimi porównaniami warto jako punkt wyjścia polecić prace: J. Tazbir, Kultura szlachecka w Polsce: rozkwit, upadek, relikty, Warszawa 1983; A. Wyczański, Polska Rzecza Pospolita szlachecka, Warszawa 1991; idem, Polska w Europie XVI stulecia, Poznań 1999; Polska w epocy odrodzenia. Państwo - społeczeństwo - kultura, Warszawa 1970.

${ }^{67}$ Patrz m.in. A. Sucheni-Grabowska, Walka o demokracje szlachecka [w:] Polska w epoce odrodzenia, op. cit., s. 9-67.

${ }^{68} \mathrm{~W}$ słynnej mowie pogrzebowej, cytowanej przez Tukidydesa w Wojnie peloponeskiej (wyd. pol. Warszawa 1988, ks. 2, rozdz. 6). 
wolności i praworządności, rozumianych zresztą zgodnie z greckim pierwowzorem $^{69}$; czyli w wielu punktach odmiennie od rzymskiej tradycji republikańskiej. Myśliciele rzymscy, w tym sam Cycero, akceptowali równość obywateli, rozumianą jako punkt dojścia; tzn. bilansującą wkład jednostki w budowę wspólnego dobra (znaczenie, koligacje, bogactwo) i jej wpływ polityczny. Przeciwnie demokracja, tak w wersji ateńskiej, jak i polskiej, nadawała każdemu obywatelowi tę samą rangę polityczną już w punkcie wyjścia. Równość w stanie szlacheckim była oczywiście fikcją, ale fikcją kształtującą rzeczywistość. Wprawdzie brak rodzimych tytułów arystokratycznych czy wyrażenie „brać szlachecka” możemy dzisiaj traktować z przekąsem jako wyraz nieuzasadnionej pychy - historia nieubłaganie dowiodła, że tego rodzaju równość jest dosyć wymagająca i łatwo zmanipulować ją tak, by utrwalała de facto rządy bogatej oligarchii - ale nie wolno oceniać idei wyłącznie na podstawie jej praktycznej realizacji. Nie zawsze złe wykonanie dowodzi błędności projektu. Czasem jest wręcz odwrotnie: wskazuje ono raczej, że realizatorzy odstąpili od jego realizacji bądź też nonszalancko zlekceważyli jego podstawowe założenia.

Goślicki zdawał sobie sprawę, że równość tak pojęta prowadzić może do przewagi elementu demokratycznego, a to z kolei rodzi niebezpieczeństwo degeneracji republiki: Rzeczypospolitej - państwa, w którym polityka ma być zakorzeniona $\mathrm{w}$ etyce. Zwłaszcza, jeśli ogniwem łączącym politykę i nadrzędną sferę wartości mają być przede wszystkim jednostki, a nie prawo, czy instytucje. Cnota wymaga doskonalenia, przyzwyczajenia i nasladownictwa, a więc w naturalny sposób promuje hierarchię, podczas gdy w warunkach wyjściowej równości standardy cnotliwego działania są wyznaczane przez aktualne zdolności i umiejętności większości obywateli ${ }^{70}$. By zaradzić temu potencjalnemu zagrożeniu, Goślicki proponował wzmocnić rolę senatu. Jak wiemy, nie był w tej propozycji odosobniony:

„A przeto wielką pilność król czynić ma okoła obierania tych urzędników, któremi zwyczaj jest zasadzać koło senatorskie, które jest najwyższą rzeczypospolitej radą, pospolitego dobra i zacności stróżem, które króla i zwierzchnego pana do pięknych a uczciwych rzeczy pobudza, od pospolitych nieuczciwych odwodzi, a złe jego chęci hamuje; bez którego rady, zdania i zwierzchności nic w rzeczypospolitej ani za granicą czynić się nie godzi" ${ }^{\prime 1}$

${ }^{69}$ Goślicki w zasadzie nie odrzuca wartości związanych z teorią demokratyczną, ale chce na ich bazie skonstruować porządek republikański. Sam przyznaje, że wzorował się do pewnego stopnia na monarchii ateńskiej, opisywanej przez Tukidydesa; por. W. Goślicki, op. cit., s. 95.

${ }^{70}$ W. Goślicki, op. cit., s. 63.

${ }^{71}$ A. Frycz-Modrzewski, O poprawie Rzeczypospolitej. O obyczajach, tekst na stronie Wirtualnej Biblioteki Literatury Polskiej: http://f.polska.pl/files/193/174/242/O_poprawie_Rzeczypospolitej.pdf, s. 19. 
- pisał Andrzej Frycz-Modrzewski. W myśl podobnych rozwiązań, cnota senatorów miała być zinstytucjonalizowana w porządku prawnym, by zapobiegać korupcji systemu politycznego, często będącego przedmiotem przetargu między uprawnieniami króla a uprawnieniami szlachty. Dla Goślickiego senat, koniecznie złożony z osób najcnotliwszych w państwie, stanowi właściwy punkt ciężkości, zdolny wyważyć i zneutralizować rywalizację między królem (zainteresowanym wzmocnieniem swej władzy) i pragnącą wolności szlachtą. Wzmocnienie senatu, jak argumentuje autor, jest wzmocnieniem wykonawczej władzy królewskiej, choć w sposób alternatywny wobec rodzącego się ówcześnie absolutyzmu. ,Jak bowiem - pisze Goślicki - ręka podzielona na palce jest bardziej sposobna i silniejsza do chwytania wszystkich rzeczy, tak i król używając przy kierowaniu państwem towarzyszy, pomocników i doradców, będzie rządził lepiej i roztropniej"72. Będzie w dodatku mądrzejszym i cnotliwszym królem, przejmując od swych doradców najlepsze ich cechy ${ }^{73}$. Całe dzieło Goślickiego - od tytułu poczynając - jest argumentacją na rzecz tego stanowiska, a także konstrukcją osobowego wzorca „doskonałego senatora"74, który ma zrównoważyć (ale nie zniszczyć) demokratyczne akcenty ustroju Rzeczypospolitej konkurencyjną zasadą pozwalającą zachować arystotelesowski ,złoty środek”. W przeciwieństwie do Arystotelesa jednak (godzącego wolność z majątkiem i uzupełniającego obydwie mądrością), Goślicki zdaje się w swych poszukiwaniach wybierać drogę wskazaną przez Platona - zachęca bowiem do promocji swoistego ,nieumiarkowania” w cnocie, które stając się źródłem władzy (dzięki współdziałaniu króla i senatu), zapanuje nad ekscesami szlacheckiej wolności. Zarazem wolności tej nie unicestwi, lecz zachęci do uwzględnienia przy jej realizacji wymogów cnoty, powiązanej z systemem wartości wspólnotowych, uniwersalnych zasad sprawiedliwości i prawa naturalnego. Zakorzeniona na takim gruncie wolność będzie mogła pozostać w sferze politycznej (wspólnej), a mimo to zachować swój indywidualny charakter, bez szkody dla dobra ogółu. Trudno oprzeć się wrażeniu, że tego rodzaju myślenie polityczne zaciążyło istotnie nad rozwojem polskiej myśli politycznej. Skłaniało bowiem do utożsamiania wolności jednostki z uczestnictwem we władzy politycznej (czyli promowało, jak określiłby to Benjamin Constant ,wolność starożytnych”), a lokując wagę i prestiż działań jednostkowych w sferze publicznej, negowało zasadność oddzielenia od niej tzw. sfery prywatnej. Cóż bowiem za wartość mogło mieć tworzenie wokół jednostki obszaru niezależnego od państwa i społeczeństwa, skoro taka „wol-

${ }^{72}$ W. Goślicki, op. cit., s. 77.

${ }^{73}$ Ibidem.

${ }^{74}$ Książka należy do popularnego w renesansie gatunku literatury parenetycznej, tzw. ,zwierciadła" (speculum), którego przykładem jest m.in. Ksiązę N. Machiavellego czy Dworzanin polski Ł. Górnickiego. Tego rodzaju prace koncentrują się na podaniu opisu - a nawet bardziej „przepisu” - na najlepszego wykonawcę pewnej roli społecznej, zachęcając do jego naśladowania. 
ność negatywna”, jak nazwą ją liberałowie, ograniczać miała się tylko do sterowania własnym losem. Polski obywatel-szlachcic decydował zaś o losach całego społeczeństwa (nie można zapominać o konkretnej władzy szlachty nad chłopstwem, a po części i mieszczaństwem) i państwa, zwłaszcza że dysponował w tym zakresie zupełnie wyjątkowym narzędziem, jakim stało się liberum veto (nie bez przyczyny uznane za „źrenicę” wolności). Konsekwencje tego stanu rzeczy znamy, ale nie należy ich przyjmować bezkrytycznie. Różnica między polskim republikanizmem a republikanizmem weneckim, a zwłaszcza angielskim, jest istotna i okazała się brzemienna w skutki. Jednak z doktrynalnego punktu widzenia ideologia szlachecka zasługuje na uważne potraktowanie nie tylko z uwagi na swą wewnętrzną spójność, ale także walory argumentacyjne, możliwe do wykorzystania także dzisiaj; między innymi jako narzędzie testowe, sprawdzające współczesne koncepcje neorepublikanizmu, z ich naciskiem na znaczenie obywatelstwa i zaangażowania obywateli w życie publiczne - co jest niczym innym jak próbą udoskonalenia demokracji przez cnotę właśnie, a także ponownego włączenia wolności w sferę życia wspólnotowego.

$\mathrm{Na}$ koniec jeszcze jedna hipoteza, która wymagałaby dalszych badań, ale mogłaby służyć obronie dziedzictwa polskiego republikanizmu i jego zastanawiająco nieumiarkowanej promocji cnoty obywatelskiej, kosztem pozostałych elementów, takich jak troska o jakość systemu prawnego czy sprawność instytucjonalną państwa.

Skoro każda $\mathrm{z}$ analizowanych koncepcji eksponuje odmienny fundament dobrej republiki, można zapytać: co się stanie, kiedy z takich czy innych względów zostanie on usunięty? Wenecjanie ufali trwałości zapisanego w prawie porządku republikańskiego do tego stopnia, że mimo widocznych oznak upadku gospodarczego i politycznego państwa, koncentrowali się głównie na działaniu w sferze prywatnej. Podkreśla się, że schyłek Republiki Weneckiej nie znajdował odzwierciedlenia w życiu jej obywateli - wiek XVIII to jednocześnie ponowny rozkwit kultury i sztuki oraz coraz dłuższe karnawały, zabawy i uroczystości. A że prawo stosunkowo łatwo zmienić, na fali nastrojów rewolucyjnych, po wkroczeniu entuzjastycznie witanego Napoleona, zdecydowana większość Wielkiej Rady postanowiła jedną decyzją zlikwidować tysiącletnią Najjaśniejszą Republikę (12 V 1797), co samemu Contariniemu nie mieściłoby się w głowie. Również Smith nie przewidywał z pewnością, że stabilna organizacja społeczeństwa angielskiego i jej zwieńczenie w postaci instytucji centralnych może ulec kryzysowi tak poważnemu, jak miało to miejsce w XVII stuleciu. Pisząc swe dzieło, nie zdawał sobie sprawy, że z chwilą gdy dwie z wychwalanych przez niego instytucji - król i parlament - wystąpią przeciwko sobie, wagi zasadniczej nabiorą konkretne uprawnienia i kompetencje, regulujące prawnie zakres ich władzy i wzajemne relacje. Sam dosyć niefrasobliwie, jak pokazało późniejsze wykorzystywanie 
jego słów, pisał o ,absolutnej” władzy parlamentu i ,,absolutnej” władzy króla, ufając komplementarności i skłonności do współpracy tychże. Wojna domowa w Anglii dowiodła, że współpraca ta nie jest tak oczywista, jak mogłoby się wydawać. $Z$ drugiej strony jednak nie można zaprzeczyć, że w dłuższej perspektywie właśnie angielskie instytucje życia społecznego wykazały swą żywotność i siłę, eliminując nie tylko niezgodne z ich rozwojem tendencje absolutystyczne, ale i projekty Oliviera Cromwella. W tym sensie diagnoza Smitha, sprowadzająca specyfikę Republica Anglorum do zauważalnego prymatu instytucji, zyskała historyczne potwierdzenie.

I wreszcie, I Rzeczpospolita, ufundowana na jednostkowej cnocie, nie potrafiła eksternalizować tejże cnotliwości na tyle, by wpisać ją w porządek prawny i polityczny kraju. A kiedy miejsce cnoty zajęły własne interesy i korzyści („niewidoczne” dla tego rodzaju teorii republikanizmu), spoczywające na barkach obywateli państwo nie mogło sprawnie funkcjonować. Charakterystyczne, że rozczarowanie rodzimą ideologią, winioną często za klęskę rozbiorów, było tak wielkie, iż do dzisiaj w powszechnej świadomości (i podręcznikach historii) strażnikami patriotyzmu w czasach oświecenia są wyłącznie reformatorzy z kręgu Hugona Kołłątaja, Ignacego Potockiego i Stanisława Staszica, którzy w gruncie rzeczy postanowili wstrząsnąć ustrojowymi podstawami państwa w oparciu o obce, głównie francuskie i angielskie wzory i rozwiązania. Zapominamy, że druga strona - tzw. republikanci (Adam Wawrzyniec Rzewuski) - również zgłaszała postulaty reform; często pod względem stopnia praktycznego radykalizmu posuwające się znacznie dalej. Co więcej, nie ma powodu, by redukować wpływ myślenia republikańskiego tylko do zaplecza ideowego Rzeczpospolitej szlacheckiej i zamykać refleksji nad nim ostatnim, minorowym akordem jej upadku. Tak jak w przypadku Anglii wywarło ono bowiem konkretny wpływ na dalszą polską tradycję polityczną. Idee mają bowiem to do siebie, że same nie biorą się znikąd, lecz stanowią artykulację przekonań i poglądów zrodzonych w długim procesie budowy tożsamości kulturowej, a potem spłacają ten dług odciskając na niej swe piętno. Być może nie jest przypadkiem, że przez 123 lata zaborów przetrwała polityczna (nie tylko narodowa) identyfikacja polskości, nakazująca nieustanne starania o poszukiwanie sposobów odzyskania niepodległości. „Odzyskania” właśnie - traktowanego jako formalne potwierdzenie ciągłości państwa, nawet jeśli przejściowo istniejącego tylko w sferze wspólnych wartości. Być może z powodu republikańskiego rozumienia wolności (realizowanej przez uczestnictwo polityczne) tak trudno przecierał sobie szlaki polski liberalizm, a polski socjalizm nie tylko zdecydowanie odrzucał marksistowskie plany zniesienia państwa (z wyjątkiem wąskiej grupy „prawdziwych” komunistów w rodzaju Róży Luksemburg), lecz skupiał uwagę na kwestiach etycznych, rozpatrywanych z perspektywy jednostki. Możliwe, że bez utożsamienia państwa $\mathrm{z}$ obywatelami i przekonania tych ostatnich, iż są czymś 
więcej niż tylko „osobami prywatnymi”, nie mielibyśmy aż tyle do powiedzenia o zaskakującej sile polskiego ruchu oporu w czasie II wojny światowej, a później funkcjonowaniu ,alternatywnego” społeczeństwa obywatelskiego w czasach komunizmu. W tych przypadkach Polska - rzecz pospolita należąca do obywateli polskich nie miała ani własnego prawa, ani własnych instytucji; ale tworzyła jedno i drugie w oparciu o jednostki dostrzegające polityczną wagę własnych działań i ich znaczenie dla wspólnego dobra.

Budowa porządku państwowego z wykorzystaniem potencjału tkwiącego $\mathrm{w}$ jednostkach okazała się niełatwa w tych momentach, kiedy rozwój państwa wymagał raczej scementowania sfery publicznej za pomocą praw i instytucji władzy - ale kiedy właśnie instytucje i prawo zawodziły (lub zostały zawłaszczone przez inne państwa), ta sama cecha polskiej tradycji politycznej okazywała się zaletą. Trudno oprzeć się wrażeniu, że w takich sytuacjach rozpadu wspólnoty państwowej Polacy po prostu ,upychali po kieszeniach” te kawałki Rzeczypospolitej, za które wcześniej byli publicznie odpowiedzialni, troszcząc się o nie często bardziej niż wówczas, kiedy stanowiły jeszcze elementy jednej układanki. Może więc nadmierne zaufanie do cnotliwości obywateli nie było wyborem do końca trafionym na etapie budowy modelu ustrojowego I Rzeczpospolitej, ale pomagało zachować jej wspólnotowo-polityczny charakter, wiążąc go z etyką indywidualnego działania. Nadawało to od początku szczególnie postępowy i demokratyczny rys polskiej myśli politycznej. „Cnota - zakończmy słowami Goślickiego - z jakiego bądź stanu wynosi się ponad los, jest dla wszystkich dostępna, nikogo nie odrzuca, wszystkich jednakowo przygarnia" 75 .

THREE TIMES RES PUBLICA:

THOMAS SMITH, GASPARO CONTARINI AND WAWRZYNIEC GOŚLICKI

\section{Summary}

The interest in Republican thought is on the increase again, now chiefly thanks to the works of Quentin Skinner and the circle of so-called neo-Republicans (or civic Republicans) concentrated around Phillip Petit. They stress the peculiar perspective that Republicans have had on the state and society. This is seen in their distinctive view of freedom as the absence of domination, or attachment to the category of citizenship and the related role of civic virtues. These special characteristics justify, in their opinion, distinguishing the Republican trend of political thought (historically and now) from other positions, especially the liberal tradition.

Accepting generally the above opinion, the paper draws our attention to significant differences within Republicanism itself. To do this, it cites the three conceptions

${ }^{75}$ W. Goślicki, op. cit., s. 135. 
of republic that were formed in the $16^{\text {th }}$ century and refer to England (Sir Thomas Smith), Venice (Gasparo Contarini) and Poland (Wawrzyniec Goślicki). Although they were formed around the same time and have common roots mainly in Aristotle's philosophy and Roman Republican ideas, each of the three perspectives views the republic from a different angle.

While all three authors believe the coexistence of three elements - orderly institutions, wise law and virtuous citizens - to be crucial for any state, they rely in their deliberations on one element only. This has an impact on the way their conceptions finally appear and on the conclusions for the political system they draw. And so, Smith gives precedence to institutions, Contarini emphasises the key role of law and Goślicki gives primacy to virtue, concentrated in an ideal senator. Taking notice of such differences among thinkers openly admitting to an attachment to the Republican tradition should make us even more careful so as not to oversimplify it as if it were uniform and completely cohesive. Further, the awareness of such differences may provoke reflection how justified the use of the Republican banner is in respect of so different authors as, for instance, Machiavelli and Montesquieu.

TROIS FOIS LA RES PUBLICA:

THOMAS SMITH, GASPARO CONTARINI ET WAWRZYNIEC GOŚLICKI

\section{Résumé}

L'intérêt suscité par la pensée républicaine renaît aujourd'hui surtout grâce aux ouvrages de Quentin Skinner et ceux du milieu dit néo-républicains (ou autrement civic republicans), concentrés autour de Philip Pettit. Tous, ils indiquent la spécificité de la conception républicaine de l'État et de la société qui se manifeste, entre autres, par une liberté caractéristique, entendue comme l'absence de domination ou l'attachement à la catégorie de citoyenneté et au rôle des vertus citoyennes qui s'y rattachent. Cette spécificité justifie, selon eux, la distinction entre le courant républicain de la pensée politique (du point de vue historique et contemporain) et d'autres positions, surtout de la tradition libérale. Adhérant de manière générale à la conviction ci-dessus, l'article attire toutefois notre attention sur les différences significatives au sein du républicanisme - même. À cet effet, il évoque trois conceptions de la république, nées au XVI ${ }^{\mathrm{e}}$ siècle. Elles décrivent l'Angleterre (T. Smith), Venise (G. Contarini) et la Pologne (W. Goślicki). Même si l'époque de leur naissance est similaire et les racines idéologiques communes puisent principalement dans la philosophie d'Aristote et les idées républicaines romaines, chacune de ces visions de la république suit un chemin un peu différent. Les trois auteurs considèrent que la question clé pour l'État est la coexistance de trois éléments: institutions hiérarchisées, droit sensé et citoyens vertueux, mais chacun d'entre eux basera le poids des réflexions sur l'un de ces éléments ce qui ne restera pas sans effet pour la forme définitive de leur conception et des conclusions pour le régime qui en découlent. Ainsi, Smith donne 
la priorité aux institutions, Contarini met en exergue le rôle clé du droit et Goślicki met accent sur la primauté de la vertu habitant un sénateur parfait. Le fait de saisir ce type de différences entre les penseurs déclarant ouvertement leur attachement à la tradition républicaine devrait appeler à une plus grande prudence quant à son traitement, trop simplifié, comme tradition uniforme et totalement cohérente. Et d'autant plus cela peut conduire à la réflexion, dans quelle mesure autoriserait-on l'utilisation de l'enseigne républicaine par rapport aux auteurs aussi différents que Machiavelli et Montesquieu, par exemple. 